\title{
Kemik İliği Stroması: Hücreleri ve Mikroçevresi
}

\author{
Aynur KARADA $\breve{G}^{1}$, Buket ALTINOK², Tülin ÖZKAN ${ }^{3}$, Yalda HEKMATSHOAR \\ ${ }^{1}$ Uşak Üniversitesi Tıp Fakültesi Tıbbi Biyoloji AD, Uşak, Türkiye \\ ${ }^{2}$ Ankara Üniversitesi Sağllk Hizmetleri Meslek Yüksekokulu, Ankara, Türkiye \\ ${ }^{3}$ Ankara Üniversitesi Tıp Fakültesi Tıbbi Biyoloji AD, Ankara, Türkiye \\ E-mail: aynkaradag@gmail.com,aynur.karadag@usak.edu.tr
}

\begin{abstract}
Özet
Kemik iliği olgunlaşmamış ve olgunlaşmış kan hücrelerinin yapısal stromal hücrelerle kapatıldığı özel bir yerdir. Bu süngerimsi yă̆ dokusu, insan kafatası, göğüs kafesi, kaburgalar, pelvis ve femurlar gibi kemiklerin içinde bulunur. Kemik iliği, sinüzoid olarak adlandırılan özelleştirilmiş fenestra kapiller dahil olmak üzere, uzmanlaşmış kan damarları aracılığıyla beslenir ve dolaşıma bağlanır. Bu sinüzoidler retiküler fibroblastlar tarafından üretilen sünger benzeri hücre dışı matrise (ECM) nüfuz eder ve bu hücreler ve proteinler, hematopoietik hücreleri ayrı bölmelere yerleștirir. Kemik iliğinde, hematopoietik hücreler, stromal hücreler, ECM, sitokinler, büyüme faktörleri ve kemokinler ihtiva eden özel mikroçevreler bulunur. Bu mikroçevrede gelişmekte olan hematopoietik hücreler hayatta kalmak, farklılaşmak ve çoğalmak için sinyal alırlar. Kemik iliği mikroçevresi löseminin ve diğer kanser türlerinin gelişiminde ve ilerlemesinde önemli bir rol oynamaktadır. Birçok yönden, kemik iliği malign hücrelerin büyümesi için ideal bir mikroçevre sağlamaktadır. $\mathrm{Bu}$ derlemede, kemik iliği mikroçevresinin görevi ve mikroçevreyi oluşturan hücrelerin hakkında genel bilgi verilmiştir.
\end{abstract}

Anahtar Kelimeler: Kemik iliği, Hematopoetik kök hücre, Mezenkimal kök hücre, Mikroçevre

\begin{abstract}
Bone marrow is a specialized site of structural stromal cells of immature and mature blood cells. It is found in bones such as the human skull, rib cage, ribs, pelvis and femur. Bone marrow is connected to the invention and circulation through specialized blood vessels, including specialized fenestrated capillaries called sinusoids. These sinusoids penetrate sponge-like extracellular cells which is produced by fibroblasts, and place hematopoietic cells, proteins in separate compartments. Bone marrow contains specialized microchips containing hematopoietic cells, stromal cells, ECM, cytokines, growth factors and chemokines. In this microenvironment, developing hematopoietic cells are signaling for survival, differentiation and proliferation. Bone marrow microenvironment plays an important role in the development and progression of leukemia and other types of cancer. In many ways, bone marrow provides an ideal microenvironment for growth of malignant cells. In this review, general information about the role of the bone marrow microenvironment and the cells forming the microenvironment is given.
\end{abstract}

Key words: Bone marrow, Hematopoietic stem cell, Mesenchymal stem cell, Microenvironment 


\section{Giriş}

Kök hücre nişleri, kök hücrelerin bakımını teşvik eden ve işlevlerini düzenleyen özel mikro ortamlardır. Son gelişmeler, yetişkin hematopoietik kök hücrelerini (HKH'leri) koruyan nişleri anlamamızı geliştirmiştir. Bu ilerlemeler arasında HKH'ler ve niş hücreler için yeni belirteçler, niş faktörlerin ekspresyon modellerinin sistematik analizleri, niş hücrelerin işlevsel olarak in vivo olarak tanımlanması için genetik araçlar ve geliştirilmiş görüntüleme teknikleri yer alıyor. Birlikte, HKH nişlerinin kemik iliğinde ve dalakta perivasküler olduğunu gösterdiler. Endotel hücreleri ve mezenkimal stromal hücreler bu nişlerde HSC bakımını teşvik eden faktörleri salgılar, ancak diğer hücre tipleri HSC nişlerini doğrudan veya dolaylı olarak düzenler. Bu derlemede kemik iliği stromasını oluşturan hücreler ve mikroçevre elemanları ele alınacaktır.

\section{Normal Kemik İliği Mikroçevre Bileşenleri ve Fonksiyonları}

Hematopetik kök hücreler (HKH) kemik iliği mikroçevresinde, özelleşmiş alan olan nişlerinde bulunmakta ve kendi kendini yenilemektedirler. Kemik iliği (Kİ) nişi kök hücrelerin sessizliğini, çoğalmasını, farklılaşmasını ve göçünü düzenler. Kök hücreler, adezyon mekanizmaları da dahil olmak üzere çeşitli moleküler sinyalleri değiştirerek niş ile etkileşirler. Kİ, osteoblastik (endosteal) ve vasküler nişlerdeki iki farklı mikroçevre nişinin uyum içinde çalıştıkları gösterilmiştir (Perry and Li, 2007). Osteoblastik niş, bol miktarda kemik oluşturan osteoblastlarla kemik boşluğunun iç yüzeyinde lokalizedir. Osteoblastik nişte HKH'ler ve osteoblastlar adezyon molekülleri vasitasıly birbirlerine bağlanır ve bu bağlanma kök hücre sessizliğinin korunmasına katkıda bulunmaktadır (Iwasaki and Suda, 2009).

Kemik iliği hücre tipleri işlevsel olarak hematopoietik, parankimal, stromal veya mezenkimal olarak sinıflandırılabilir. Normal hematopoez, hematopoietik hücreler, stromal hücreler ve ECM bileşenlerinden oluşan karmaşık bir kemik iliği mikroçevresinde ortaya çıkar. Hematopoietik progenitör proliferasyonu ve farklılaşması, sitokinler ya da progenitörler ile stromal hücreler ya da bu mikroçevredeki ekstra selüler matriks (ECM) bileşenleri arasındaki etkileşimler tarafından başlatılan reseptör aracılı sinyaller ile düzenlenir (Tabe and Konopleva, 2014). Kemik iliği mikroçevresinin anatomik ve işlevsel çeşitliliğini ortaya çıkarmak, HSC'lerin davranışlarını anlamak ve bu bilgileri klinik uygulamalar için kullanmak için çok önemlidir (Şekil1).

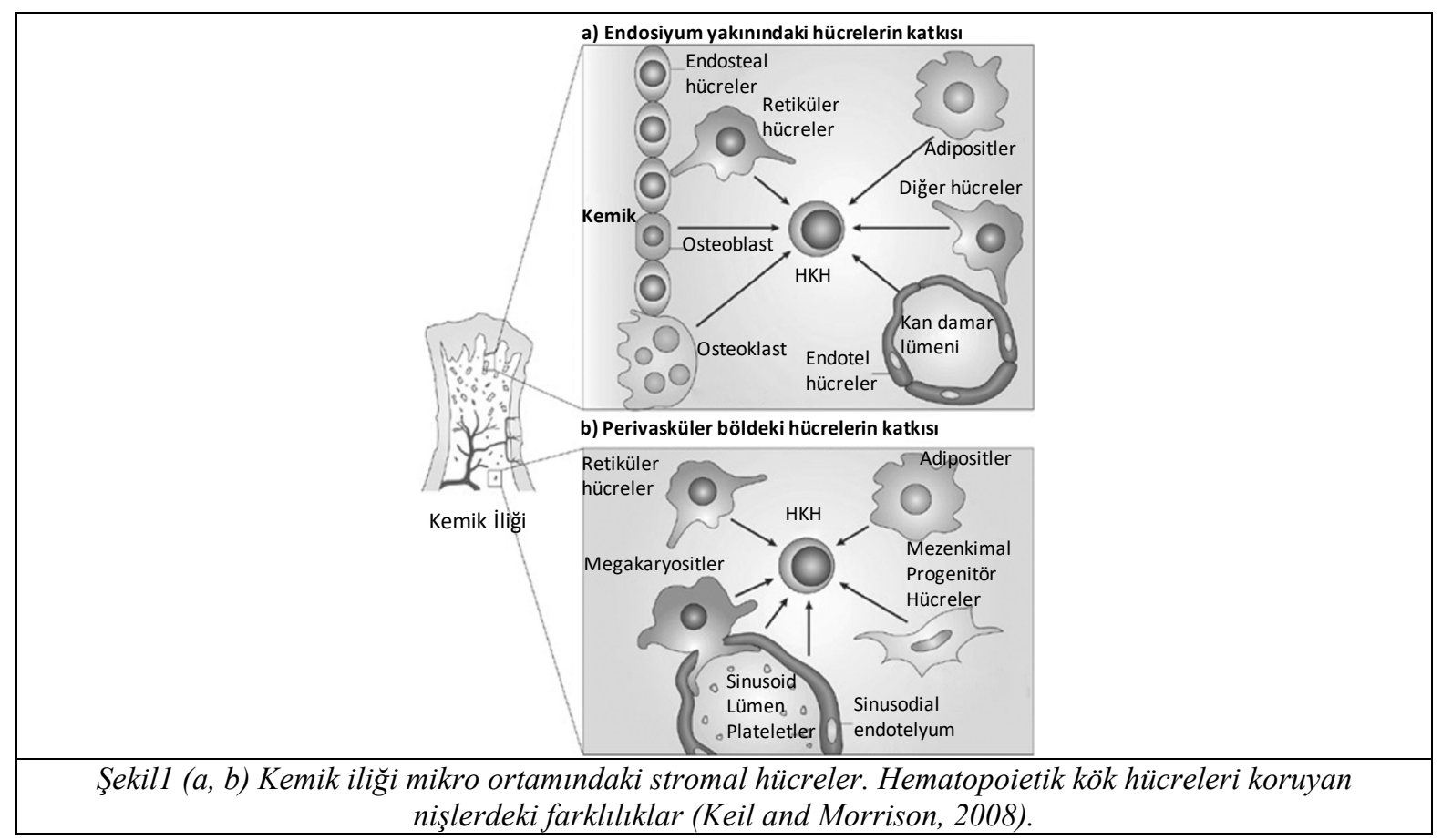




\section{Stromal Hücreler}

Kemik iliği stroması, doğrudan hematopoezde rol almayan bir bağ dokudur. Bununla birlikte, stroma içindeki mezenkimal hücreler, hematopoezi kolaylaştıran yapısal bir mikroçevre sağlamaktadır. Mezenkimal hücreler, sitokinler, büyüme faktörleri ve ECM proteinleri üretirler. Mezenkimal hücreler, kök hücre sessizliğini ve kendi kendine yenilenmesini modüle ederek hematopoezi teşvik eder, aynı zamanda daha olgun hematopoietik hücrelerin çoğalması, olgunlaşması ve apoptosise yol açan sinyalleri de sağlamaktadırlar. Kemik iliği stromasını oluşturan mezenkimal hücre türleri şunları içerir: mezenkimal kök hücreler (MKH), fibroblastlar, adventif retiküler hücreler, adipositler, osteoblastlar, osteoklastlar, endotel hücreleri ve endotel öncü hücrelerdir.

\subsection{Mezenkimal kök hücreler (MKH'ler)}

Mezenkimal kök hücreler Pittenger ve ark. Tarafından tanımlanan kemik iliğinde bulunan hematopoietik olmayan kök hücrelerdir (Pittenger et al. 1999). Araştırmacılar bundan önce, koloni oluşturan birim fibroblast (CFU-F), stromal kök hücre, kemik iliği stromal kök hücreleri, kemik iliği hücreleri, mezoderm progenitör hücreler (Reyes et al., 2001; Dippolito et al., 2004), multipotent stromal hücreler veya iskelet kök hücreleri (Prockop, 1997; Kuznetsov et al., 2001) gibi bu popülasyon için çeşitli terimler kullanmışlardır. Belirli koşullar altında MKH'ler, fibroblastlar, osteoblastlar, osteositler, kondrositler, adipositler, adventisit retiküler hücreler, düz kas hücreleri, endotel hücreleri, miyelosupportif stroma ve sinir dokusuna farklılaşabilmektedir (Pittenger et al., 1999; Bianco et al., 2008).

MKH, Stro-1, Thy-1, vasküler hücre adezyon molekülü-1, endoglin, $\alpha 1$ integrin ve MUC-18 / CD146 gibi belirli belirteçlerin ekspresyonu ile tanımlanabilir (Pittenger et al., 1999; Dennis and Charbord, 2002). İnsan kemik iliği stromal hücresi (hMSC), flow sitometri ile analiz edildiğinde SH-2, SH-3 ve SH-4 monoklonal antikorları ve CD14, CD34 ve CD45 ekspresyonu eksikliği ile tanımlanabilir. MKH çok sayıda sitokin ve kemokin üretmektedir. İnsan MKH'lerin 105 kemik iliği hücresinde 1 siklıkta olduğu tahmin edilmektedir. Hematopoietik kök hücreler (HKH) gibi, MKH'lerde kemik iliğine ev sahipliği yapabilmektedir (Devine et al., 2001).

\subsection{Fibroblastlar}

Fibroblastlar, kemik iliği stromal hücrelerinde en iyi çalışılanlarıdır. Kemik iliği fibroblastları, interlökin (IL) -6, granülosit-makrofaj koloni uyarıcı faktör (GM-CSF) (Guba et al.,1992), granülosit koloni uyarıcı faktör (G- CSF) (Fibbe et al., 1988a; Kaushansky et al., 1988), trombopoietin (TPO) (Guerriero et al., 1997), kök hücre faktörü (SCF) gibi çok çeşitli sitokin ve büyüme faktörü üretebilmektedir. Ayrıca tip I ve III prokollajeni I/III oranı ile sentezler (Bainton et al., 1986). Fibroblastlar, hematopoietik hücrelerin yapıştığ 1 yapısal bir iskele üretirler. Fibroblastlar, hematopoietik kök hücrelerin bağlandığ1, a4ß1 için bir ligand olan vasküler hücre adhezyon molekülü (VCAM) -1 gibi adezyon moleküllerini ifade eder (Avraham et al., 1992).

\subsection{Adventisyel retiküler hücreler}

Adventif retiküler hücreler, kemik iliği sinüzoidlerine hemen komşu ve dişında bulunan stromal hücrelerdir. Trilaminer sinüs duvarı endotel hücrelerinden oluşur; az gelişmiş bir ince taban zarı; ve adipositler haline dönüşebilen fibroblastlar olan adventif retiküler hücreler burda bulunur. Endotel ve retiküler hücreler hematopoietik sitokinlerin kaynağıdır. Mel-CAM veya melanoma hücre adezyon molekülü (MCAM), MUC18, A32 antijen ve S-Endo-1 olarak da bilinen CD146, adventisit retiküler hücreleri tanımlamak için kullanılmıştır (Sacchetti et al., 2007; Bianco et al., 2008; Shih, 1999). CD146, heterofilik hücreden hücre etkileşimlerine katılan bir $\mathrm{Ca}^{2+}$ 'dan bağımsız hücre adezyon molekülü olarak işlev gören bir membran glikoproteindir (Shih, 1999). CD146 ${ }^{+}$hücreleri anjiyopoietin-1 eksprese eder ve mural hücreleri, niş hücreleri ve osteojenik progenitörlerin özelliklerine sahiptir. Adventif retiküler hücreler VCAM-1, alkalin fosfataz ve alfa aktini ifade eder ve CXC kemokin ligand1 12 (CXCL), IL-7 
ve SCF'yi üretirler. CXCL12 adventif retiküler hücreler tarafindan sağlanan destekleyici nişler içerisinde HKH'yi tutmada rol alan bir kemokindir (reseptörü (CXCR) 4 ile birlikte) (Porter and Calvi, 2008). Adventif retiküler hücreler aynı zamanda vaskülogenezi yönlendirir ve kemik iliğindeki kan damarlarını stabilize eder (Moore and Lemischka, 2006).

\subsection{Adipositler}

Kemik iliği adipositleri, MKH'lerden türetilir. Pre-adipositler olarak adlandırılan adiposit progenitörleri, hematopoietik hücrelerin olgunlaşması ve proliferasyonu için gerekli olan sitokinleri ve ECM proteinlerinin bazılarını sağlamaktadırlar. Kemik iliği adipositleri, artmış hematopoez veya osteogenezisi gerektiren acil durumlar için lokalize bir enerji rezervuarı sağlamaktadır (Gimble et al.,1996).

Kemik iliğinde, $\mathrm{MKH}^{\prime} l e r i n$ adipositlere veya osteoblastlara diferansiyasyonu, kemik morfogenik proteinlerinden (BMP'ler), Wnt proteinleri, Hedgehog proteinleri delta/jagged proteinleri, fibroblastik büyüme faktörleri (FGF'ler), insülin, insülin benzeri büyüme faktörleri (IGF'ler) ve proliferatoractivated receptor- $\gamma(\operatorname{PPAR} \gamma)$ and runt-related transcription factor $2(\mathrm{Run} \times 2)$ gibi adiposit ve osteoblast farklılaşmasının transkripsiyonel regülatörleri dahil olmak üzere kompleks sinyal yolakları arasında çapraz iletişim yoluyla rekabetçi bir şekilde dengelenir (Nuttall and Gimble, 2004; Muruganandan et al., 2009).

Adipositler, kısmen GM-CSF ve G-CSF gibi büyüme faktörlerinin az üretilmesinden dolay1, farklılaşmamış stromal veya preadipocytic benzerlerine göre, in vitro olarak hematopoezi daha az desteklemektedir (Corre et al., 2006). Ayrica adipoz doku, her biri, hematopoietik proliferasyonu engelleyen nöropilin-1'i (Belaid-Choucair et al., 2008), lipokalin 2'yi (Miharada et al., 2008; Yan et al., 2007), adiponektini ve tümör nekroz faktörünü- $\alpha$ (TNF- $\alpha$ ) salgılamaktadır. Dikkat çekici bir şekilde, TNF- $\alpha$ ve adiponektin progenitör aktivitesini inhibe ederken, optimal proliferasyon için en ilkel HKH'leri pozitif olarak düzenler, bu da adipositlerin hematopoietik kök hücre havuzunu muhafaza ederken hematopoietik progenitör genişlemesini engellediğini düşündürmektedir (Dimascio et al., 2007).

\subsection{Osteoblastlar}

Osteoblastlar da mezenkimal hücrelerden türemiştir ve trabeküler kemiğin endosteumunun yüzeyinde bulunurlar (Mackie, 2003). Endosteum yüzeyi osteoblastlar ve osteoklastlar tarafından kaplanmıştır. Osteoblastlar, osteogenez sürecinde osteoklastlar ile birlikte çalışan progenitör kemik oluşum hücreleridir (Schroder et al., 2012). Osteoblastik nişte osteoblastlar üzerindeki Jagged-1 (Jag-1) ve HKH'ler üzerindeki NOTCH reseptörü üzerindeki sinyalizasyonu, HKH havuzunun genişlemesinde rol oynamaktadır (Calvi et al., 2003). Öte yandan, osteoblastlardaki anjiyopoietin-1 (Ang-1), HKH'lerde eksprese edilen reseptör tirosin kinaz (RTK) reseptörü olan Tie-2 ile etkileşime girer ve bu da $\beta 1$ integrin ve N-cadherin'in aktivasyonuyla sonuçlanır. Niş hücresi ve kök hücre arasındaki bu artan yapışma, kök hücre sessiz kalmasının muhafaza edilmesine de katkıda bulunur (Arai et al., 2004).

Osteoblastlar, G-CSF, makrofaj koloni uyarıcı faktör (M-CSF), GM-CSF, IL-1, IL-6, lösemi inhibitör faktörü (LIF), TNF- $\alpha$, vasküler endotelyal büyüme faktörü (VEGF), transforme edici büyüme Faktörü (TGF) - $\beta 1$ ve hematopoez düzenleyen anjiopoietin-1 üretirler (Arai et al., 2004; Taichman and Emerson, 1998) ve osteopontin gibi, HKH sayısını negatif olarak düzenleyen çeşitli matris proteinlerini de salgilarlar (Taichman and Emerson, 1998). Osteoblastlar, kaderinler, immünoglobülinler, integrinler ve selektinler ve ECM dahil bir dizi reseptör-ligand hücre adhezyon molekülü aracıllğıyla hematopoietik hücrelerle etkileşmektedirler.

\subsection{Osteoklastlar}

Osteoklastlar, hematopoietik orijinlidirler ve koloni oluşturan birim granülosit-makrofaj (CFU-GM) 'den türemiştir. Osteoklastlar, kemik rezorpsiyonunu ve HSC homeostazını düzenlemek için tartarata 
dirençli asit fosfataz (TRAP), matriks metalloproteinaz-9 (MMP-9), IL-6, IL-1, TGF- $\beta$ eksprese ederler. Osteoklast fonksiyonu MKH'ler ve osteoblastlar ile çapraz konuşma ile kontrol edilmektedir (Roodman, 1999; Reddy and Roodman, 1998). Osteoklastlar HKH nişlerinin oluşturulmasında osteoblastik gelişiminini düzenler ve daha da önemlisi endosteal nişi oluşturan boşlukları oluştururlar (Schroder et al., 2012). Osteoklastların aktivitesi, lokal ve sistemik kalsiyum iyonu konsantrasyonunu daha da yükseltir ve yayınlanan çalışmalar, endosteal nişte HKH engraftmanının, HKH'lerde ifade edilen kalsiyumduyarlı reseptör (CaR) tarafından belirlendiğini göstermiş̧tir (Adams et al., 2006).

\subsection{Endotel hücreleri}

Endotel hücreleri, kemik iliği yoluyla kan taşıyan kan damarlarını düzenler. Kemik iliği, kemik iliği bölgelerine kan akışı kontrol eden zayıflamış arteriollere kan iletimini sağlayan arterleri besler. Arterioller, oksijenlenmiş kanları, duvarları tek bir endotel hücresi tabakasından oluşan sinüzoidlere iletirler. Sinüzoidler karmaşık üç boyutlu bir yapı oluşturur.

Sinüsoidal endotel sadece hematopoietik progenitörlerin trafiğini ve homingini denetleyen bir kapıy1 kontrol etmekle kalmaz aynı zamanda hücresel teması sağlar ve hematopoetik olgunlaşmanın çeşitli yönlerini teşvik eden sitokinleri salgılar (Rafii et al., 1997; Shiozawa et al., 2008).

Sinüsoid endotel hücreleri, G-CSF, GM-CSF, M-CSF, Kit-ligand, IL-6, fetal karaciğer kinaz-2 ligandı ve LIF gibi soy özgül sitokinleri üretir. Hematopoietik progenitör hücreler ile kemik iliği endotel hücreleri (BMEC) tek tabakaları arasındaki doğrudan hücresel temas, hematopoietik kök hücrelerin trafiği ve proliferasyonunda kritik bir rol oynamaktadır. Bu temasa, very late antijen-4 (VLA-4), $\beta 2$ integrinleri ve selektinler gibi $\beta 1$ integrinleri içeren spesifik adezyon molekülleri arac1lı etmektedir (Rafii et al., 1997; Shiozawa et al., 2008).

BMEC'ler ayrıca CXCL12'ye bağlanan kemokin reseptörü CXCR4'ü ifade eder ve insan CD34 hematopoietik kök ve progenitörleri kemik iliğine götürür BMEC'ler tromboplastide de kritik bir rol oynamaktadır. CXCL12 ve FGF-4 megakaryositlerin BMEC'lere lokalizasyonu ve yapışmasına neden olur. Megakaryositlerin ve BMEC'ler arasındaki doğrudan temas, vasküler endotelyal (VE)-kadherin ve/veya VLA-4/VCAM-1 aracılığıyla trombositlerin yaşamını, olgunlaşmasını ve salınımını uyarır (Dar et al., 2005; Shiozawa et al., 2008).

\subsection{Endotel öncü hücreler}

Endotelyal öncül popülasyonların tanımları ve isimleri, alanda karışıklığa yol açmaktadır. Periferik kandaki dolaşımdaki endotel hücrelerinin farklı alt popülasyonlarının kökeni ve immünofenotipik özellikleri hakkında sıkça tutulan bir model Steurer et al., (2008) tarafından anlatılmıştır. Sirkülasyon endotel öncülleri veya progenitör hücreler (CEPler), insan periferik kanında dolaşan endotel öncü veya progenitör hücreler (EPC'ler) olarak tanımlanmıştır.

CEP'ler postnatal vaskülojeneze katkıda bulunan kemik iliği EPC'lerinden köken almıştır. CEP'leri tanımlamak için kullanılan hücre yüzey proteinleri uniform değildir. CEP'ler, Ulex europeus lectin 1 gibi lektinleri bağlama yeteneği ve asetillenmiş düşük yoğunluklu lipoproteinlerin (Ac-LDL) alımı ile karakterizedir. Daha öncül endotel progenitörleri CD34, CD133 ve vasküler endotelyal büyüme faktörü reseptör-2'yi (VEGFR2, kinaz reseptörü) eksprese ederken, daha olgun hücreler CD133 yokluğuyla karakterizedir. Olgunlaşma sırasında hücreler, CD31 (trombosit/endoethelial hücre adezyon molekülü), CD144 (VE-Cadherin) ve von Willebrand faktörü (vWF) gibi endotelyal belirteçlerin ekspresyonunu upregüle eder (Untergasser et al., 2006). Kemik iliğindeki pluripotent kök hücreler, hematopoietik progenitör hücrelere (HPC'ler) veya EPC'ye farklılaşma kapasitesine sahip olan 'hemanjioblast' ları oluştururlar. EPC, CEP'lerin ve CEC'lere farklılaşırlar. HPC, myeloid endotel hücrelere transdiferansiye olabilen monositle gibi miyeloid hücrelere farklılaşırlar. Damar duvarından gelen olgunlaşmış EC'ler dolaşıma girebilir (Steurer et al., 2008). 


\section{Diğer Mikroçevre Hücreleri}

\subsection{Makrofajlar}

Kemik iliğinde bulunan makrofajlara sabit makrofajlar denir. Makrofajlar, sayısız homeostatik, immünolojik ve inflamatuar süreçlerden sorumlu mononükleer fagositlerdir. Mezenkimal kök hücreler yerine hematopoietik kök hücrelerden türetilen tek mikro çevreci hücre popülasyonudur. Makrofajlar, pan-hematopoetik markör CD45 ekspresyonuna göre diğer mikroçevre hücrelerinden ayırt edilebilir. Makrofajlar, özellikle tümörigenez sırasında anjiyogeneziyi düzenler ve sekresyon ürünleri vasıtasıyla anjiyogenezi teşvik eder.

Makrofajlar, Kılcal endotelin mitozlarını indükleyen birkaç faktör salgılar veya üretirler. Temel fibroblast büyüme faktörü-B (bFGF), TGF- $\alpha$, GM-CSF, M-CSF, VEGF, vasküler geçirgenlik faktörü (VPF), IL-8 ve P maddesinin (SP) mitojenik etkileri iyi tanımlanırken, IGF-I, somatomedin C ve trombosit kaynaklı büyüme faktörünün (PDGF) proliferatif etkileri endotel hücrelerinde daha fazla tanımlanmasını gerektirebilir (Ribatti et al., 2007). Aktive makrofajlar PDGF üreten trombositlerin yanı sıra tek kan hücreleridir. Makrofajlar aynı zamanda, monosit türevi endotel hücresi inhibe edici faktör (MECIF), makrofaj türevi endotel hücre inhibitörü (MD-ECI), trombospondin I, interferon (IFN)- $\alpha$ ve IFN- $\gamma$ gibi endotel hücrelerinin migrasyonunu veya mitozunu inhibe eden birkaç faktörü de salgılarlar (Lamagna et al., 2006). Makrofajlar, tümör anjiyogenezindeki önemli rollerine ek olarak tümör metastazında önemli bir rol oynarlar. Bazı solid tümörler çok sayıda tümör ile ilişkili makrofaj (TAM) içerir (Balkwill ve Mantovani, 2001). TAM epidermal büyüme faktörü (EGF), FGF-2, TGF- $\alpha$ ve $-\beta$, VEGF, TNF-a, IL-1, IL-6, IL-8, trombosit aktive edici faktör, PDGF, G-CSF, ve GM-CSF, timidin fosforilaz ve CCL2 gibi kemokinleri eksprese eder ve sag1larlar. Buna ek olarak, TAM'lar trombospondin-1, IL-12, IL-18 ve MMP-9-12 gibi anjiyojenik faktörler üretirler. TAM'lar, MMP-2, MMP-9, MMP-12 ve Siklooksijenaz-2 (COX-2) gibi bazal zar ve ECM'nin bütünlüğünü bozan, matrikse bağlı faktörleri serbest bırakan çeşitli proteinaz aktivatörlerini ve inhibitörlerini üreterek doku yeniden modellenmesine neden olurlar (Ribatti et al., 2007).

\subsection{Megakaryositler}

Megakaryositler trombosit üretiminden sorumlu olan poliploid kemik iliği hücreleridir. Megakaryositler, tipik bir eritrositten 10 ila 15 kat daha büyüktür, çap1 ortalama 50-100 $\mu$ m'dir. Megakaryosit üretiminin birincil sinyali TPO'dur. Megakaryopoezi uyaran diğer moleküler sinyaller GM-CSF, IL-3, IL-6, IL-11, IL-12 ve eritropoietini içerir (Pang et al., 2005). Stromal hücre kaynaklı faktör-1 (SDF-1; CXCL12) ve trombosit faktörü 4 (PF4, CXCL4) megakaryopoez ve trombosit üretimi üzerinde de önemli etkilere sahip İki kemokindir. IL-1 $\alpha$ ve LIF de dahil olmak üzere diğer sitokinler, megakaryosit matürasyonunu ve trombosit salımını modüle eder. Trombosit üreterek hemostazda önemli bir rol oynamaktan başka, megakaryositlerin diğer önemli rolü vardır. Megakaryositler, Anjiyopoietin, BFGF, $\beta$-tromboglobulin, PF4, EGF, G-CSF, GMCSF, SCF, IFN-a, TGF- $\beta$, TNF-a, IL1, -3-9 ve -11, LIF, PDGF, MMP-2 ve -9 ve VEGF, ifade ederek ve salg1layarak, kemik iliğindeki en önemli mikroçevre hücrelerinden birini oluştururlar.

Megakaryositler, anjiyogenez, inflamasyon, ateroskleroz, antimikrobiyal konakçı savunması, yara iyileşmesi, kemik homeostazı ve maligniteyi düzenler (Blair and Flaumenhaft, 2009; Kacena and Horowitz, 2006). Kemik yeniden düzenlenmesinde kilit rol oynamaktadır. Örneğin, megakaryositler, BMP 2, 4 ve 6, nükleer faktör $\kappa$ B ligandı için reseptör aktivatörü (Kartsogiannis et al., 1999; Sipe et al., 2004), N-metil -d-aspartik asit tipi glutamat reseptörleri (Genever et al.,1999), kalsiyum algilayan reseptörler, osteonektin, osteokalsin kemik sialoprotein, osteopontin, osteoprotegerin, TGF- $\beta$ ve bunların reseptörleri ve östrojen reseptörleri (Bord et al., 2001) gibi birtakım kemik düzenleyici faktörleri ifade eder. TPO, osteoklastojenezi inhibe eder. Megakaryosit sayısının artması kemik iliği fibrozu ve osteoskleroz ile ilişkilidir (Kacena et al., 2006). 


\section{Ekstraselüler Matriks}

Hematopoietik mikroçevrenin ekstraselüler kompanenti (ECM), hücre çoğalması ve farklılaşmasının düzenlenmesinde önemli rol oynamaktadır. Genel olarak, ECM'ler kollajen, kollajen olmayan glikoproteinler, proteoglikanlar ve az miktarda diğer proteinlerden oluşur (Kreis and Vale, 1999). Bu bileşenlerin tip ve miktarlarındaki değişiklikler, farklı dokularda ECM'lerin karakteristik özelliklerini oluştururlar. Kemik iliği ECM molekülleri fibronektin (FN), kollajen, hiyalüron, heparin sülfat, tenasin, proteoglikanlar, osteonektin, osteopontin, vitronektin, laminin ve kemik sialoproteinleri içerir. Hücrematriks etkileşimi veya ECM'nin parçalanması HKH'lerin G-CSF, plerixafor hidroklorür (AMD3100) ve IL-8 gibi ajanlar tarafından mobilizasyonuna yol açar (Link, 2000; Broxmeyer et al., 2005).

\subsection{Fibronektin}

Fibronektin (FN), 450-kDa'lık fibril oluşturan bir glikoproteindir ve kemik ilği mikroçevresinin önemli bir bileşeni olan iki altbirimden oluşur. FN, kemik iliği stromal (endotel ve fibroblastlar) ve hematopoietik hücreler tarafindan üretilir ve HKH'lerin iliğe hominginde aracılık etmektedir. FN, hücreleri, büyüme faktörlerini ve ECM bileşenlerini bağlayabilir. FN'nin farklı bölgeleri, $\alpha 4 \beta 1$ (VLA4) ve $\alpha 5 \beta 1$ (VLA-5) gibi farklı integrinler ile etkileşime girer. Fibronektinin integrin reseptörleri eksprese eden hücreler üzerindeki etkileri için çoklu moleküler mekanizmalar önerilmiştir ve bu etkileşimler, tüm bu mikroenvironmental sinyaller sınıfının destekleyici etkileri için bir paradigma olarak görev alır (Abboud and Lichtman, 2006).

\subsection{Hiyalüronik asit (hiyalüronan)}

Hiyalüronan (hiyalüronik asit veya hiyalüronat), lösemi de dahil olmak üzere birçok kanser tipinin ilerlemesiyle ilişkili bir proteoglikandır. Hyalüronik asit, hiyalüronanın bir parçası olan bir GAG'dır. Hematopoietik kök hücreler hyaluronana karşı CD44 olarak adlandırılan bir reseptör ifede ederler. Çoğu HSC, CD44' ü ifade etmesine rağmen, bunların yalnızca bir kısmı hiyalürona yapışır. CD44'e karşı antikorlar, HKH'ler ile kemik iliği arasındaki etkileşimi bloke edebilir. HSC'ler ayrıca, kemik iliğinde tutunma ve proliferasyonu artıran hyaluronan üretirler (Abboud and Lichtman, 2006). Lösemi hücreleri ile hylauronan arasındaki etkileşim, löseminin ilerlemesinde önemlidir. CD44 ve hiyalüronik asit aracılı motilite için reseptör (RHAMM), kronik lenfositik lösemide upregüle edilmiştir ve zayıf prognoz belirteçleri olduğu gösterilmiştir (Giannopoulos et al., 2009). RHAMM özellikle normal hematopoietik kök ve progenitör hücreler üzerinde eksprese edilmez, ancak miyeloma, kronik lenfositik lösemi, kronik miyeloid lösemi (KML) ve akut miyeloid lösemi hücrelerinde farklı şekilde eksprese edilir. RHAMM'yi hedef alan aş1lar klinik faaliyet göstermiştir (Schmitt et al., 2008).

\subsection{Kollajen}

Kolajen, diğer ECM bileşenleri gibi kemik iliğinde kemik gelişimi için yapısal destek sağlayan kritik bir yapısal proteindir. Kolajen, retikülin adı verilen uzun fibriller oluşturur. Retikülin normal kemik iliklerinde bol miktarda bulunur. myeloid ve eritroid progenitörleri de dahil olmak üzere çeşitli hematopoietik hücre hatları ve kemik iliği mononükleer hücreleri, tip I ve VI kollajene kuvvetle bağlanırlar (Thiele and Kvasnicka, 2007).

\subsection{Heparan sülfat}

Hematopoiyi destekleyen uzun vadeli kültürler heparan sülfat proteoglikan (HSPG) tabakası geliştirir. İmmunokimyasal analiz, kemik iliği stromal hücre dizilerinin, heparan sülfatın syndecan ailesinden glypican, betaglycan ve perlecan da dahil olmak üzere birçok üyesini sentezlediğini ve saldığını göstermiştir. Yapılan çalışmalar, Heparan sülfat içeren proteoglikanların kök hücre nişinin yaşamsal bileşenleri olabileceğini göstermişlerdir. Örneğin, uzun vadeli hematopoezi destekleyen stromal hücre dizilerinden salgılanan heparan sülfat yapısı, desteksiz stromal hücre dizilerinden salgılanan heparan 
sülfata göre anlamlı derecede daha büyük ve daha sülfatlıdır. Uzun vadeli kültürlere ilave edildiğinde, heparin sülfatın daha büyük biçimlendirici maddeleri, uzun vadeli kültür başlatan hücreleri desteklerken, daha küçük, desülfatlanmış formu bunu yapamamaktadır (Gupta et al.,1998).

\section{Sonuç}

Kemik iliği mikroçevresi, normal ve malign hematopoez desteklemek için ideal bir yerdir. Mikroçevreyle olan etkileşimlerin normal hematopoezi artırdığını ve lösemi ilerlemesine katkıda bulunduğunu anlamaya başliyoruz. Hematopoetik nişi oluşturan interaktif stromal hücre kompleksinin, endosteyal bölgenin niş regülasyonundaki rolünün ve perivasküler mikroçevrelerin fonksiyonel farklılıklarının araştırılması ile mikroçevre arasındaki etkileşimleri hedef alan yeni terapiler, tek başlarına veya diğer kanser terapileri ile kombine etkili tedaviler olabilir.

\section{Kaynaklar}

ABBOUD, C.N. AND LICHTMAN, M.A. (2006). Structure of the marrow and the hematopoietic microenvironment, in Williams Hematology, 7th edn (eds M.A. Lichtman, E. Beutler, T.J. Kipps et al.), McGraw-Hill, New York, pp. 45-52.

ADAMS, G.B., CHABNER, K.T., ALLEY, I.R., OLSON, D.P., SZCZEPIORKOWSKİ, Z.M., POZNANSKY, M.C., KOS, C.H., POLLAK, M.R., BROWN, E.M., SCADDEN, D.T. (2006). Stem cell engraftment at the endosteal niche is specified by the calcium-sensing receptor. Nature. 439:599-603.

ARAI, F., HIRAO, A., OHMURA, M., SATO, H., MATSUOKA, S, TAKUBO K, ITO K, KOH GY, SUDA T. (2004). Tie2/ angiopoietin-1 signaling regulates hematopoietic stem cell quiescence in the bone marrow niche. Cell.; 118:149-161.

AVRAHAM, H., SCADDEN, D.T., CHİ, S. ET AL. (1992) Interaction of human bone marrow fibroblasts with megakaryocytes: role of the c-kit ligand. Blood, 80, 1679-1684.

BAINTON, D.F., MALONEY, M.A., PATT, H.M., AND STERN, R. (1986) Characterization of rabbit stromal fibroblasts derived from red and yellow bone marrow. Journal of Experimental Medicine, 163, 400-413.

BALKWILL, F. AND MANTOVANI, A. (2001) Inflammation and cancer: back to Virchow? Lancet, 357, 539-545.

BELAID-CHOUCAIR, Z., LEPELLETIER, Y., PONCIN, G. ET AL. (2008) Human bone marrow adipocytes block granulopoiesis through neuropilin-1-induced granulocyte colony-stimulating factor inhibition. Stem Cells, 26, 1556-1564.

BIANCO, P., ROBEY, P.G., AND SIMMONS, P.J. (2008) Mesenchymal stem cells: revisiting history, concepts, and assays. Cell Stem Cell, 2, 313-319.

BLAIR, P. AND FLAUMENHAFT, R. (2009) Platelet alpha-granules: basic biology and clinical correlates. Blood Reviews, 23, 177-189.

BORD, S., BEAVAN, S., IRELAND, D. ET AL. (2001) Mechanisms by which high-dose estrogen therapy produces anabolic skeletal effects in postmenopausal women: role of locally produced growth factors. Bone, 29, 216-222. 
BROXMEYER, H.E., ORSCHELL, C.M., CLAPP, D.W. ET AL. (2005) Rapid mobilization of murine and human hematopoietic stem and progenitor cells with AMD3100, a CXCR4 antagonist. Journal of Experimental Medicine, 201, 1307-1318.

CALVI, L.M., ADAMS, G.B., WEIBRECHT, K.W., WEBER, J.M., OLSON, D.P., KNIGHT, M.C., MARTIN, R.P., SCHIPANI, E., DIVIETI, P., BRINGHURST, F.R., MILNER, L.A., KRONENBERG, H.M., SCADDEN, D.T. Osteoblastic cells regulate the haematopoietic stem cell niche. Nature. 2003; 425:841-846.

CORRE, J., BARREAU, C., COUSIN, B. (2006) Human subcutaneous adipose cells support complete differentiation but not self-renewal of hematopoietic progenitors. Journal of Cellular Physiology, 208, 282-288.

DAR, A., GOİCHBERG, P., SHINDER, V. ET AL. (2005) Chemokine receptor CXCR4-dependent internalization and resecretion of functional chemokine SDF-1 by bone marrow endothelial and stromal cells. Nature Immunology, 6, 1038-1046.

DENNIS, J.E. AND CHARBORD, P. (2002). Origin and differentiation of human and murine stroma. Stem Cells, 20, 205-214.

DEVINE, S.M., BARTHOLOMEW, A.M., MAHMUD, N. ET AL. (2001). Mesenchymal stem cells are capable of homing to the bone marrow of non-human primates following systemic infusion. Experimental Hematology, 29, 244-255.

DIMASCIO, L., VOERMANS, C., UQOEZWA, M. ET AL. (2007). Identification of adiponectin as a novel hemopoietic stem cell growth factor. Journal of Immunology, 178, 3511-3520.

DIPPOLITO, G., DIABIRA, S., HOWARD, G.A. ET AL. (2004). Marrow-isolated adult multilineage inducible (MIAMI) cells, a unique population of postnatal young and old human cells with extensive expansion and differentiation potential. Journal of Cell Science, 117, 2971 - 2981.

FIBBE, W.E., VAN DAMME, J., BILLIAU, A. ET AL. (1988). Human fibroblasts produce granulocyte-CSF, macrophage-CSF, and granulocytemacrophage-CSF following stimu- lation by interleukin-1 and poly(rI). poly(rC). Blood, 72, 860-866.

GENEVER, P.G., WILLKINSON, D.J., PATTON, A.J. ET AL. (1999). Expression of a functional Nmethyl-D-aspartate-type glutamate receptor by bone marrow megakaryocytes. Blood, 93, 2876 2883.

GIANNOPOULOS, K., MERTENS, D., BUHLER, A. ET AL. (2009). The candidate immunotherapeutical target, the receptor for hyaluronic acid-mediated motility, is associated with proliferation and shows prognostic value in B-cell chronic lymphocytic leukemia. Leukemia, 23, 519 $-527$.

GIMBLE, J.M., ROBINSON, C.E., WU, X., AND KELLY, K.A. (1996). The function of adipocytes in the bone marrow stroma: an update. Bone, 19, 421-428.

GUBA, S.C., SARTOR, C.I., GOTTSCHALK, L.R. ET AL. (1992). Bone marrow stromal fibroblasts secrete interleukin- 6 and granulocytemacrophage colony-stimulating factor in the absence of inflammatory stimulation: demonstration by serum-free bioassay, enzyme- linked immunosorbent assay, and reverse transcriptase polymerase chain reaction. Blood, 80, 1190-1198.

GUERRIERO, A., WORFORD, L., HOLLAND, H.K. ET AL. (1997). Thrombopoietin is synthesized by bone marrow stromal cells. Blood, 90, 3444-3455. 
GUPTA, P., OEGEMA, T.R. JR., BRAZIL, J.J., ET AL. (1998). Structurally specific heparan sulfates support primitive human hematopoiesis by formation of a multimolecular stem cell niche. Blood, 92, 4641-4651.

IWASAKI H, SUDA T. (2009). Cancer stem cells and their niche. Cancer Science. 100:1166-1172.

KACENA, M.A., GUNDBERG, C.M., AND HOROWITZ, M.C. (2006) A reciprocal regulatory inter- action between megakaryocytes, bone cells, and hematopoietic stem cells. Bone, 39, 978 - 984.

KARTSOGIANNIS, V., ZHOU, H., HORWOOD, N.J. ET AL. (1999) Localization of RANKL (receptor activator of NF kappa B ligand) mRNA and protein in skeletal and extraskeletal tissues. Bone, 25, 525-534.

KAUSHANSKY, K., LIN, N., AND ADAMSON, J.W. (1988) Interleukin 1 stimulates fibroblasts to synthesize granulocyte-macrophage and granulocyte colony-stimulating factors. Mechanism for the hematopoietic response to inflammation. Journal of Clinical Investigation, 81, 92-97.

KIEL, M.J., MORRISON, S.J. (2008). Uncertainty in the niches that maintain haematopoietic stem cells. Nat Rev Immunol 8: 290-301.

KREIS, T. AND VALE, R. (1999). Extracellular Matrix, Anchor, and Adhesion Proteins, Oxford University Press, Inc., New York.

KUZNETSOV, S.A., MANKANI, M.H., GRONTHOS, S. et al. (2001). Circulating skeletal stem cells. Journal of Cell Biology, 153, 1133-1140.

LAMAGNA, C., AURRAND-LIONS, M., AND IMHOF, B.A. (2006). Dual role of macrophages in tumor growth and angiogenesis. Journal of Leukocyte Biology, 80, 705-713.

LINK, D.C. (2000). Mechanisms of granulocyte colony-stimulating factor-induced hematopoi- etic progenitor-cell mobilization. Seminars in Hematology, 37, 25-32.

MACKIE, E.J. (2003). Osteoblasts: novel roles in orchestration of skeletal architecture. International Journal of Biochemistry and Cell Biology, 35, 1301-1305.

MIHARADA, K., HIROYAMA, T., SUDO, K. ET AL. (2008). Lipocalin 2-mediated growth suppression is evident in human erythroid and monocyte/macrophage lineage cells. Journal of Cellular Physiology, 215, 526-537.

MOORE, K.A. AND LEMISCHKA, I.R. (2006). Stem cells and their niches. Science, 311, 1880 1885 .

MURUGANANDAN, S., ROMAN, A.A., AND SINAL, C.J. (2009). Adipocyte differentiation of bone marrow-derived mesenchymal stem cells: cross talk with the osteoblastogenic program. Cellular and Molecular Life Science, 66, 236-253.

NUTTALL, M.E. AND GIMBLE, J.M. (2004). Controlling the balance between osteoblastogenesis and adipogenesis and the consequent therapeutic implications. Current Opinion in Pharmacology, 4, 290-294.

PANG, L., WEISS, M.J., AND PONCZ, M. (2005). Megakaryocyte biology and related disorders. Journal of Clinical Investigation, 115, 3332-3338.

PERRY, J.M., LI, L. (2007). Disrupting the stem cell niche: good seeds in bad soil. Cell.; 129:10451047. 
PITTENGER, M.F., MACKAY, A.M., BECK, S.C. ET AL. (1999). Multilineage potential of adult human mesenchymal stem cells. Science, 284, 143-147.

PORTER, R.L. AND CALVI, L.M. (2008). Communications between bone cells and hematopoietic stem cells. Archives of Biochemistry and Biophysics, 473, 193-200.

PROCKOP, D.J. (1997). Marrow stromal cells as stem cells for nonhematopoietic tissues. Science, $276,71-74$.

RAFII, S., MOHLE, R., SHAPIRO, F. ET AL. (1997). Regulation of hematopoiesis by microvascular endothelium. Leukemia and Lymphoma, 27, 375-386.

REDDY, S.V. AND ROODMAN, G.D. (1998). Control of osteoclast differentiation. Critical Reviews in Eukaryotic Gene Expression, 8, 1-17.

REYES, M., LUND, T., LENVIK, T. ET AL. (2001). Purification and ex vivo expansion of postnatal human marrow mesodermal progenitor cells. Blood, 98, 2615-2625.

RIBATTI, D., NICO, B., CRIVELlATO, E., AND VACCA, A. (2007) Macrophages and tumor angiogen- esis. Leukemia, 21, 2085-2089.

ROODMAN, G.D. (1999) Cell biology of the osteoclast. Experimental Hematology, 27, 1229 1241.

SACCHETTI, B., FUNARİ, A., MICHIENZI, S. ET AL. (2007). Self-renewing osteoprogenitors in bone marrow sinusoids can organize a hematopoietic microenvironment. Cell, 131, 324-336.

SCHMITT, M., SCHMITT, A., ROJEWSKİ, M.T. ET AL. (2008). RHAMM-R3 peptide vaccination in patients with acute myeloid leukemia, myelodysplastic syndrome, and multiple myeloma elicits immunologic and clinical responses. Blood, 111, 1357-1365.

SCHRODER HC, WANG XH, WIENS M, DIEHL-SEIFERT B, KROPF K, SCHLOßMACHER U, MÜLLER WE. (2012). Silicate modulates the cross-talk between osteoblasts (SaOS-2) and osteoclasts (RAW 264.7 cells): inhibition of osteoclast growth and differentiation. Journal of Cellular Biochemistry; 113:3197-3206.

SHIH, I.M. (1999) The role of CD146 (Mel-CAM) in biology and pathology. Journal of Pathology, $189,4-11$.

SHIOZAWA, Y., HAVENS, A.M., PIENTA, K.J., AND TAICHMAN, R.S. (2008) The bone marrow niche: habitat to hematopoietic and mesenchymal stem cells, and unwitting host to molecular parasites. Leukemia, 22, 941-950

SIPE, J.B., ZHANG, J., WAITS, C. ET AL. (2004) Localization of bone morphogenetic proteins (BMPs)-2, -4, and -6 within megakaryocytes and platelets. Bone, 35, 1316-1322.

STEURER, M., KERN, J., ZITT, M. ET AL. (2008) Quantification of circulating endothelial and progenitor cells: comparison of quantitative PCR and four-channel flow cytometry. BMC Research Notes, $1,71$.

TABE, Y., KONOPLEVA, M., (2014). Advances In Understanding The Leukemia Microenvironment Br J Haematol. March; 164(6): 767-778.

TAICHMAN, R.S. AND EMERSON, S.G. (1998) The role of osteoblasts in the hematopoietic microenvironment. Stem Cells, 16, 7-15. 
THIELE, J. AND KVASNICKA, H.M. (2007) Myelofibrosis what's in a name? Consensus on definition and EUMNET grading. Pathobiology, 74, 89-96.

UNTERGASSER, G., KOECK, R., WOLF, D. ET AL. (2006) CD34+/CD133- circulating endothelial precursor cells (CEP): characterization, senescence and in vivo application. Experimental Gerontology, 41, 600-608.

YAN, Q.W., YANG, Q., MODY, N. ET AL. (2007) The adipokine lipocalin 2 is regulated by obesity and promotes insulin resistance. Diabetes, 56, 2533-254. 